\title{
PERFORMATIVE SUBJECTHOODS: LESBIAN REPRESENTATIONS IN SPLIT BRITCHES' BELLE REPRIEVE
}

\author{
INMACULADA BENÍTEZ OLIVAR \\ Universidad de Sevilla \\ inmolivar@gmail.com
}

Received 28 June 2020

Accepted 8 February 2021

\section{KEYWORDS}

Split Britches; Gender; Sexuality; American Theater; Lesbianism; Feminism; Lesbian Representations; Queer; Heteropatriarchy; Belle Reprieve.

\section{PALABRAS CLAVE}

Split Britches; Género; Sexualidad; Teatro Norteamericano; Lesbianismo; Feminismo; Representaciones Lésbicas; Queer; Heteropatriarcado; Belle Reprieve.

\begin{abstract}
Emerging postmodern theories of gender and sexuality frame the terms in which society has understood these concepts in an evolutionary way throughout history. The last century has witnessed the radical changes carried out mainly by feminist and LGTB movements. On the other hand, the theater, a subversive space where it is possible to experiment with different forms of subjecthood and communication, has been the laboratory in which it has been attempted to give a plastic form to these new currents of thought. In this sense, the work of Split Britches is remarkable for the innovative ways of bringing the abject to the political forefront. From the lesbian body to drag representation, Belle Reprieve (1991) is developed under the queer premise to dismantle heteropatriarchal hegemony and the binary gender system.

\section{RESUMEN}

Las emergentes teorías postmodernas del género y la sexualidad enmarcan los términos en los que la sociedad ha entendido estos conceptos de manera evolutiva a lo largo de la historia. El siglo pasado ha sido testigo de los cambios más o menos radicales llevados a cabo principalmente por los movimientos feministas y LGBT. Por otra parte, el teatro, un espacio subversivo donde es
\end{abstract}


posible experimentar con diferentes formas de subjetividad y de comunicación, ha sido el laboratorio desde el que se ha tratado de dar una forma plástica a estas nuevas corrientes de pensamiento. En este sentido, la obra de Split Britches es destacable por las novedosas formas de traer lo abyecto a un primer plano politico. Desde el cuerpo lesbiano hasta la representación drag, Belle Reprieve (1991) es desarrollada bajo la premisa queer, con el fin de desmantelar la hegemonía heteropatriarcal y el sistema binario de género.

\section{THE POLITICAL DISCOURSES OF THE BODY: GENDER AND SEXUALITY}

It was already in 1949 when Simone de Beauvoir's statement "One is not born, but rather becomes, a woman" (274) was largely disseminated among theorists of feminism and other cultural studies. De Beauvoir laid the foundations for the continual questioning of the category 'woman' and allowed other philosophers to continue the research on the incongruence of biological assertions and the effects of discourse upon sex and gender identity. After much debate throughout decades, Monique Wittig in The Straight Mind continues challenging the role of women and their position in society by declaring that women's oppression is based on history and biological arguments. She considers sex and gender as political categories that define one's role in society, so against this thought, she claims that "there is no nature in society" (13). However, and this may be Wittig's Achilles heel, she proposes to exit the category 'woman' in order to enter that of 'lesbian'. This poses two problematic ideas. First, she is falling into the same contradiction by making the category of 'lesbian' a natural one instead of a social construct like the rest of labels. Second, Wittig presupposes the inherent subversion of the category of 'lesbian' as a political instrument that may disrupt the heterosexual matrix. More recently, Judith Butler, in a critique to the former philosopher, brings some new light to gender and sex considerations from a postmodern and poststructuralist point of view. In her opinion, it would be a mistake to construct a lesbian/gay identity "through the same exclusionary means, as if the excluded were not, precisely through its exclusion, always presupposed" (Gender Trouble 163).

To comprehend the construction of the subject, it is 
interesting to attend to Jacques Lacan's theory of subject formation through the mirror reflection of the Other. From a psychoanalytical perspective, Lacan believes that it is only through the recognition in a mirror that an infant is able to recognize himself/herself and this would lead to the symbolic structure and formation of his/her subjectivity. He supports the vision of the subject where the figure of the Other is essential to the formation of identity structures. In his own words:

What I have called the mirror stage is interesting in that it manifests the affective dynamism by which the subject originally identifies himself with the visual Gestalt of his own body: in relation to the still very profound lack of co-ordination of his own motility, it represents an ideal unity, a salutary imago. (15)

This is, according to Lacan, how ego subjectivity is created in the early years of an infant's life, while the reflected image posits a dilemma for the infant because this image is recognized as part of himself/herself but also as some external part; some other he/she is unable to recognize but where desire starts, as it is the other's desire as well. This thought leads Lacan to believe that the infant has got the capacity to form his/her subjectivityalthough fictional-through agency. In his own words:

[...] this form situates the agency of the ego, before its social determination, in a fictional direction, which will always remain irreducible for the individual alone, or rather, which will only rejoin the coming-into-being (le devenir) of the subject. (2)

Nonetheless, Lacan is presupposing here a subject preexisting social conventions, which means that the subject is preformed independently and outside social conventions and norms. On the contrary, the American philosopher Judith Butler, far from considering the subject as a pre-existing entity, believes that it is developed under the law of institutions, discourses, and practices, arguing that the mirror stage described by Lacan coincides with the infant's entry to the symbolic order of language, so it is actually language itself and the laws derived from it the aspects that contour the politics of the body. Similar to the critique to Foucault, the problem for Butler is that Lacan is assuming a kind of materiality prior to signification and form. 
For this reason, many critics have seen a kind of "death of the subject" in Butler's idea (Salih 11) which becomes the appropriate site for reconstructing the category of the subject and thus, the appropriate site for subverting existing power structures. This supposed 'death' is not a literal one but a sort of decomposition of the subject that makes it possible to reconstruct it from a strengthened position. This transformation takes place as soon as the subject attempts to overcome its bodily limits by desiring the Other. As Butler states:

[...] what desire wants is the Other, where the Other is understood as its generalized object. What desire also wants is the Other's desire, where the Other is conceived as a subject of desire. This last formulation involves the grammar of the genitive, and it suggests that the Other's desire becomes the model for the subject's desire. [...] I desire what the Other desires (a third object), but that object belongs to the Other, and not to me; this lack, instituted through prohibition, is the foundation of my desire. (Undoing Gender 137-8)

The Other here becomes the target of prohibition, this is, the subject longs to become the other inner self that has been repressed. As a result of this prohibition, sex as much as gender are the results of the taboo against homosexuality. In this way, gender could be considered a choice, a fictive category that can be disrupted and altered as it has been constructed by discourse and the law. It is then clear enough that the role of gender acts as a way of masquerade, a repetition of patterns that have been commonly assimilated through their practices. This is where the debates about drag performances, cross-dressing acts, and femme/butch role-playing take part as they have been harshly criticized even in feminist circles because of their exaggerated imitation of masculinity and/or femininity. However, it is precisely this exaggeration which "reveals the imitative structure of gender itself" (GT 137). In other words, drag performances evince the falseness and possible imitation of naturalized forms of behavior rooted in heterosexual male/female subjects and they cause a disorder that attempts to reveal the performativity of gender. What is more, the repetition of cultural gestures and behaviors often fails and, "in that failure, open possibilities for re-signifying the terms of violation against their violating aims." (Bodies That Matter 124). This is where Butler criticizes Lacan for addressing the body 
before the symbolic world because even before being born, one has probably already entered the symbolic world of language by being assigned a fixed and immutable sex and gender and, with these labels, all the subsequent cultural implications. This is where drag performances become relevant in relation to Butler's theory of the performative:

Such acts, gestures, enactments, generally construed, are performative in the sense that the essence or identity that they otherwise purport to express are fabrications manufactured and sustained through corporeal signs and other discursive means. That the gendered body is performative suggests that it has no ontological status apart from the various acts which constitute its reality. (GT 173)

Butler's notion of subject formation through language derives in part from J. L. Austin's linguistic theory in his work How To Do Things With Words ${ }^{1}$ and, apart from her critique on Austin's work, Butlerian ideas go beyond the materiality of words and speeches, transcending any tangible aspect of subjectivity. Based on Austin's relation between discourse and the subject's formation, Judith Butler suggests the inability to set up a

${ }^{1}$ Originally published in 1962, Austin focuses on what he calls constatives and performatives. In disagreement with the traditional ideas that utterances can merely be used to describe "some state of affairs, or to 'state some fact', which it must do either truly or falsely" (1), the author distinguishes between these two notions to develop his thought. On the one hand, constative utterances define those statements that seem to merely describe a true or false statement, and these are accomplished or neglected according to their trueness/falseness. On the other hand, performative utterances are not dependent upon their true or false nature but are more related to an action that is carried out through words. Straightforwardly, what is said has a clear effect and an implicit intention, and then, issuing a performative utterance is not about describing but rather about doing something. As Austin outlines: "[...] the uttering of the sentence is, or is a part of, the doing of an action, which again would not normally be described as, or as 'just', saying something." (5). In this context, it is clear enough that when one says something, it is not just describing a state or an event but is implicitly or explicitly performing an action (or persuading someone else to do some kind of action. Judith Butler disagrees with the idea suggested in Austin's work where the speech is solely formed by the utterer since the subject and thus, the speech one might produce is not designed in solitude but is the result of a learned discourse through the words we have been exposed to. In her own words: "We do things with language, produce effects with language, and we do things to language, but language is also the thing that we do." (Excitable Speech 8). 
coherent line among the different categories of sex, gender, and sexuality. Instead, being largely influenced by Monique Wittig's idea of the straight mind as a political institution and regime as well as by Adrienne Rich and her concept of both compulsory heterosexuality and lesbian existence, Butler develops the idea of gender as "the effect of a regulatory practice that seeks to render gender identity uniform through a compulsory heterosexuality" (GT 31). In this case, the formation of the subject is nothing but a non-material substance that has been overexposed to continuous doses of binary and heterosexual forces injected through cultural assumptions and its discourses. Identity is, then, created under this unavoidable pressure that attempts to create a homogeneous and unidirectional way of being.

Furthermore, Butlerian postmodern ideas go further in the attempt to compare the imitation of gender to drag performances, a concept that helps her to deconstruct the notion of an original identity. As she notes: "the original [is] nothing other than a parody of the idea of the natural and the original." (GT 31). From this point of view, being heterosexual is no longer perpetuated as the normal nor the homosexual as the perverted, in so much as gender falls under the presupposition of its capacity of performance. Instead, both gender and sexuality become ways of cultural applications that have been somehow imposed by the heterosexual regime and we, as individuals, have the capacity to deconstruct them in terms of their ontology. To put it simply, cross-dressing, drag, and butch/femme performances can be metaphorically used in order to provide displaced forms of subjecthood with a space to safely perform their true nature while supplying them with the opportunity to become agents of subversive modes of subjecthood. However, it becomes compulsory not only to dispute whether all drag is subversive in terms of deconstructing and/or destabilizing the sex and gender hierarchy and the constraints they certainly impose on every subject through discourse, but also to discuss, if this is to be true, what are the processes and requirements by which these practices are feasible, especially with regard to postmodern theater and performances. 


\section{RE-APPROPRIATING THE STAGE: STRATEGIES FOR PERFORMING SUBVERSIVE THEATER}

Taking as background the Brechtian concept of political theater, performance itself should not be considered only a form of entertainment but also an act of resistance, denunciation, and rebellion. Despite the many varied definitions of political theater among theorists, it seems unavoidable to recall as a summary the very much disputed statement of "the personal is political." Popularized during the second wave of feminism and mainly developed by 1969 Carol Hanisch's essay "The Personal is Political," this idea gives some hints about the purposes of political theater.

In the need to agitate the stagnant and conservative theater, production from the early nineties was influenced by the prior work of playwrights such as Bertolt Brecht and Erwin Piscator. They led their performances towards the creation of new practices and strategies that allow the audience's active involvement with the play in order to provide spectators with the space and instruments to prompt critical reflection. Both playwrights promoted new forms of representation, and whereas Brecht evolved towards new forms of dramatic experience, Piscator employed strategies such as agitprop, this is, the use of political propaganda such as slogans and/or pictures to arouse in the spectator the necessity to gain political awareness. This style made it possible to reach a wide mass of people and to provide them with a closer and more realistic image of society. Involving the audience in the action, the appeal to social revolt, the bare stage, the direct approach to the audience, the destruction of the 'fourth wall', the detachment of character-performer and the short format of these plays are only some of the characteristics that are still being developed in postmodern performances.

Making theater a subversive space attempts not only to subvert and deconstruct gender ontology but also to betray traditional definitions of theater. In this sense, the postmodern ideas flowering in the sixties would eventually bring notions that oppose standardized approaches of making theater. Indeed, it came with the concept of "Re-writing all the familiar things in new 
terms and thus proposing modifications, new ideal perspectives, a reshuffling of canonical feelings and values." (Jameson xiv). Hence, it must be understood that postmodernism developed as a reaction against the high modern culture of modernism and as such, the boundaries between high culture and the so-called mass or commercial culture were demolished in favor of more overt and boundless forms of expression where the subject was no longer alienated but rather fragmented, distorted, even disappeared and impossible to categorize. However, following a postmodern theory of the performance does not guarantee the subversion of canonical concepts and for this reason, it is crucial to distinguish between those elements that make something subversive and those that repeat and consolidate heteropatriarchal hierarchies.

In the field of the subversive, Sue-Ellen Case has made great contributions by acknowledging many modes of subversion that should assist with the task of reconstructing the dialectics of power. As she observes during her research of the butch/femme lesbian bar culture of the seventies, there is a crucial necessity for denaturalizing political categories that affect the personal and thus, the way identities are considered within society. She notices how femme lesbians were not considered under the label of 'lesbian' because their appearance did not fit the standard image of the feminine, so denaturalizing the ontological feature of gender categories must be seen an assignment urgent to embrace. As she suggests, this should co-occur with the inversion of political terminology so as to confuse power relationships (58). In this regard, it seems transcendental to be aware of the importance of re-appropriating those terms that have been used as instruments to stifle and reduce minorities to exclusionary groups and to reinvent them, yet to achieve this aim it is indispensable to question and challenge ontological statuses as this act "may constitute a means of successful revolt" (Salih 135).

It may still seem confusing and even dangerous to talk about subversion by itself, as not everything that apparently disrupts standards can be taken as subversive. This is the point where drag performances and the concepts of parody and irony conflate into the attempt of gender deconstruction. Following the definition given by Linda Hutcheon, who defines parody as a process of coding-decoding where the speaker has to infer a second meaning, she believes that parody cannot be understood without irony if it is to be successfully subversive and vice versa. 
In her own terms:

Whether parody is intended as subversive of established canons or as a conservative force [...] the original text, in either case the reader has to decode it as parody for the intention to be fully realized. [sic.] (93).

Hence, one concept cannot exist without the other, and it is essential that the decoder understands the contextual background of the message that the encoder is attempting to transmit implicitly. Otherwise, if the decoder fails at the task of identifying this covert information, "he or she will merely naturalize it" and thus, "such naturalization would eliminate a significant part of both the form and content of the text" (34). Then, it is evident that the art of parody somehow conveys a complete adherence to the deconstructive process to oppose aesthetic norms because it is indeed in the power of comedy and its effects where subversion seems to be more effective.

In this context, drag performances and butch/femme roleplaying have been often used as devices through which the idea of an original (cisheterosexual) identity is parodied as it can be certainly imitated and reproduced. However, it is by means of parody that these acts adhere to their subversive intention. For Butler, "in imitating gender, drag implicitly reveals the imitative structure of gender itself - as well as its contingency" (GT 175), and by contingency it must be understood the instability of all categories as their nature rests upon fictive productions of being. However, not all drag acts must be understood as subversive, since sometimes they do act as devices that simply repeat patterns of normative behavior. Butler herself admitted that it would not be appropriate to identify parody with subversion, as some performances certainly manifest a reinforcement of stereotypes of cultural hegemony (GT 176-77).

To bring some light to this extensive debate, Fredric Jameson clearly distinguishes between the subversive power of pastiche and parody, which are directly linked to the processes of subversion in drag performances. For Jameson, pastiche is, unlike parody, "a neutral practice of such mimicry, without any of parody's ulterior motives, amputated of the satiric impulse, devoid of laughter and of any conviction" (17). This is what he calls blank parody, this is, a version of parody bare of any satirical purpose 
and thus, with no political purpose at all. This is what happens, for instance, in the very much debated documentary Paris Is Burning (1991), where drag queens seem to be under the influence of the same hegemonic conventions they are supposed to dismantle. Instead, there is a rebound effect due to the fact that Livingston, the moviemaker, presented a "highly sensationalized rendering of Latino and black transvestite and transsexual communities" along with an attempt to "glamorize the experience" (Esteban Muñoz 162). This critique to Paris Is Burning clarifies the limits of subversion, and it is clear enough that it is in the power to make political criticism that Livingston's movie fails, exhibiting instead the pleasure in the spectacle during elitist and privileged drag balls.

The same problem occurs when considering the debate on camp style. Borrowing features from both the burlesque and Art nouveau, camp became in the sixties a new artificial aesthetic that aimed to dismiss the seriousness of assumptions that had been proved to be weak constructions of subjecthood. This background reflects and explains the emergence of camp as the effect of underground culture. Irony, one of the pillars of this aesthetic is essential to show incongruent concepts that have been culturally assumed. Inherent in camp and irony, humor takes the seriousness of an issue and makes it visible from a different perspective, one funny and accessible to everybody. The funny element is attained using irony; this is, by exposing the weak foundations which pre-established notions are based on. This way, the theatricality that camp offers leads one to assume the nature of one's artifice and makes it superlative to the extent of grotesque exaggeration. Although, of course, not all camp is gay; these aesthetics serve each other in order to get support far from the mainstream, and so, camp becomes a strategy that makes it possible to explore one's identity beyond the limits of homogeneous and normative identities as well as to reinvent maleness and femaleness from a parodic point of view. Essentially, what makes drag king performances subversive is addressing the feminine even though their apparent male aesthetic, because, as Esther Newton suggests: "Even one feminine item ruins the integrity of the masculine system; the male loses his caste honor." (101). The fragility of manhood can be hyperbolically exposed by drag kinging, since drag symbolizes the illusion of an original identity as artifice. 
Esteban Muñoz's research on the subversive presents a paradigm where identities are never fixed but rather, the effect of a linguistic and cultural process where fixed dispositions shape the essence of an identity. Following Pêcheux, he advocates for a paradigm that is meant to be an explanation for dissident identities of queers, especially queers of color. He poses the idea that the subject is ideologically constructed by three modes of practices. The third stage, where Muñoz sees the opportunity to subvert hegemonic prescriptions, is that of disidentification, where the subject, as he states, is "one that neither opts to assimilate within such a structure nor strictly opposes it; rather, disidentification is a strategy that works on and against dominant ideology." (11). This instrument of subject formation attempts to denaturalize gender ontologies and provide them with new meanings and forms of being. However, the complete freedom of such a subject should not be assumed, but at least, this thought would provide it with a wider spectrum to identify with and even the means to self-identify from and within a personal axis. As well, as a way of performing subjects, Muñoz regards disidentification as the "hermeneutical performance of decoding mass, high, or any other cultural field from the perspective of a minority subject who is disempowered in such a representational hierarchy." (25), and in this transformation, he believes that there is a whole process of coding/decoding where paradigms can be parodically subverted in order to form a strong strategy for resistance.

These processes of disidentification can be reflected in Jack Halberstam's analysis of masculine performance in drag king contests. She asserts that the recent rise of these types of performances-due to the gay eclipse during the nineties-drag kings had not learnt yet how to turn masculinity into theater (245), and thus, most drag king shows were just acts of male mimicry, resulting in a reinforcement of patriarchal stereotypes. These drag performances were often a copy of male aesthetics with no sense of theatricality at all, thus deriving into an imitation of a presupposed and original male behavior. On the other hand, when the drag king implies a denaturalization of the assumed original, because their main aim is to dismantle the idea of a true original, then the drag king performance succeeds at being subversive. As Butler argues, "there is a subversive laughter in the pastiche-effect of parodic practices in which the original, the authentic and the real are themselves constituted as effects." (GT 186-7). Certainly, 
the drag king performances that actually work at their subversive purpose are those that adapt a campy role and those where hyperbole becomes a strategy to enact male sexism and misogyny.

To exemplify the subversive power of drag/cross-dressing performances, it is interesting to consider the American Charles Ludlam and his work on the Theater of the Ridiculous in the 1960s. As a pioneer of postmodern theater, his broad acting style was based on the inclusion of drag queens or cross-dressers in the cast, along with surrealistic stage settings and props that would blur the limits between reality and illusion. Thus, the parodies of consumerist society that Ludlam proposed borrowed items from popular culture and transformed them into devices for mockery and critical thinking. According to Tony Kushner, the Theater of the Ridiculous "[...] became the first openly gay aesthetic, $[\ldots]$ the political act that began the modern gay liberation movement" (31). There was a real human need to make visible and appeal to the outrageous, the queer by means of an impact, and a kind of disturbance that makes the audience react. The Theater of the Ridiculous has been recently rescued by queer theory to highlight the way in which the characteristics of Ludlam's notion of theater could be applied to contemporary plays in order to dismiss the idea of gender as an intrinsic and preexisting feature of human existence. After years of research and theatrical experimentation with cross-dressing performances, by 1967 and with the first performance of Ludlam's play Conquest of the Universe or When Queens Collide, "Ludlam was beginning to conceive of the Ridiculous as an outrageous celebration of queer identities" (Bottoms 232). This step forward characterized the Ridiculous provoking a shift as to the idea of masculine/feminine oppositions; this is, from cross-dressing performances to the impossibility to take as natural or original any type of factual identity and thus, directing towards the artificial art of drag representation. However, this kind of portrayal of drag would have been impossible unless factors such as parody, irony and even collage and pastiche -all of them used by Ludlam- were the essence and the subversive elements of his plays.

In this context, the work of Split Britches continues the tradition of feminist and queer practices from a postmodern perspective, which entails a shift in the production of the subject as it is now, presented as fragmented, parodied, and deconstructed in order to challenge a world that seems insufficient 
for a homogeneous and unique axis of desire. Lesbian bodies started to be considered within feminist discourse during the late seventies and early eighties and thus, a whole new kind of theater emerged that involved feminist and queer discussions. In this case, Split Britches shows the rise and development of women's performance and a deviation in the representation of women's desire, turning from a heterocentric theater to one that is imbued within feminist, racial, and queer issues which are all important to address. During the eighties, a whole range of feminist and lesbian theater showed up with a new aesthetic and addressing unconventional topics that differentiate them from their traditional counterparts. Troupes such as the Five Lesbian Brothers or solos like Carmelita Tropicana took a decisive and active role in the shift of perspective with regards to desire and the construction of the subject, thus creating a new concept of theater where actors base their performances on denouncing oppressive norms and which is (the new concept) closely linked to theory "interested in unmasking the system of representation and its ideological alliances." (Forte 4).

\section{UNDOING GENDER: SPLIT BRITCHES' BELLE REPRIEVE (1990)}

Split Britches is a theatrical company originally formed in the eighties by Peggy Shaw, Lois Weaver, and Deb Margolin in New York and mainly performing at the WOW Café. Disenchanted with the ways theoretical discussions were taking through the separation of feminist/queer ideas, Split Britches remained as a project "aimed to create a space for practicing alternatives to that dominant order." (Split Britches 12). Placing lesbians in the subject position and allowing them to freely explore their multiple and fluid identities, Belle Reprieve (1990) is a deconstruction of Tennessee William's play A Streetcar Named Desire. Split Britches' performances re-locate and re-signify the lesbian subject "as artifice, through butch-femme role playing." (13), making emphasis of this plasticity by including drag and cross-dressing performers who have not been assigned a fixed gender role. Regarding the background, the work of Split Britches develops in the middle of the Reagan era which highlights the activism related to AIDS or abortion so as to struggle against political conservatism. This way, the austerity of the scenery is contrasted 
with a camp style that ridicules any serious attempt of following a coherent plot.

The title of this play is interesting from a linguistic point of view since it stands as a pun-this is, a play on words that uses a similar expression but with a different meaning-on the place where Blanche lost her fortune in the southern fields of Belle Reve. Carrying the symbolic guilt of Blanche's status of femme fatale, the title is now subverted in order to signify a shift in the original considerations about the play. The title is then, a re-writing of the family's lost dreams where the sense of blame is mitigated, thus suggesting the lack of guilt for the queer representation.

Concerning the structure, Belle Reprieve is divided into two different acts with only some blackouts, which simplifies the general structure of the play at the same time that the script undergoes quantitative modifications with respect to the contents of the original play.

The characters in Belle Reprieve play one single role borrowing the literal names of the original play. However, as subjects, their bodies appear to be less sexualized from heteronormative standards and instead, they are allowed to freely 'play' gender and sexual desire. This play also presents the novelty of including drag representation, which is brought to the stage by the troupe Bloolips, a crew formed by professionals of drag queen performance. This strategy arouses in the audience the need of paying constant attention as well as encouraging it to question the authenticity of the identities represented on the stage. It may also serve the play as a method to destabilize the fixed categories of gender.

To start with, the character of Stella is no longer represented as the submissive woman we find in Williams'version but rather represents the values of feminist discourses that challenge the original version of the play. As presented by the script, Stella is "a woman disguised as a woman" (150), this is, she does not get cross-dressed, but the script challenges the trueness of Stella's womanhood, defining the performativity of this category. Also, she defies some of Stanley's butch lesbian behaviors by betraying their inappropriateness and incarnating a powerful role that mocks Stanley's depiction of a wrongly-assumed masculinity. In one of the many arguments between the couple, Stanley says: "I am not your enemy" to which Stella responds: "No... but you have many of the characteristics [...]." (169). Yet, her unconditional love 
for Stanley is symbolized by her addiction to Coke soda, a pop element that gives her this feeling of impassivity and leads her to mental paralysis. In other words, to avoid what is actually going on in the play, "Stella, who lives in a state of "narcoticized tranquility" (Boxill 77) has borrowed considerably from Blanche's narcissism while she utters feminist discourses at the same time which position her as an activist. While Williams' original play emphasized her capacity for sensuality, in Belle Reprieve, Stella notices and acknowledges her role in the play by claiming: "Look, I'm supposed to wander around in a state of narcotized sensuality. That's my part [...]". (Split Britches 151). This exposes the passive role to which her character was subjected in Williams' play. As the story unfolds, the reader suspects about Stella's ambiguity as she soon begins to give hints of her excessive admiration for her sister Blanche that results in a lesbian and incestuous sexual desire. The lesbian eroticism is made explicit in this fragment, a surmise that is made even more explicit when the two sisters remember their past as cheerleaders and in the excitement of the moment they sing:

Under the covers, it's you and it's me now / Our pleasure grows, because we are two now / [...] Under the covers, our fingers exploring / Those hidden dreams, we've found there is something. (160)

Nevertheless, the fact that the character of Blanche is performed by a drag queen, makes the relationship impossible to categorize in terms of gender. Even further, Stella closes the play leaving an unsolved mystery regarding her identity. In the last scene, when Stanley tells her "[...] you are the only thing we can rely on, because you are at least who you seem to be", Stella answers: "Well, Stanley, there's something I've been meaning to tell you..." (182). This enigma can be solved with the possibility of Stella referring to her lesbianism or instead, she may be suggesting her change of gender identity and thus, using Butler's words, exposing her Other desired identity.

The second character, performed by Peggy Shaw is literally described in the script as "a butch lesbian" (150), a definition that considerably diverges-at some levels-from that male stereotype marked by the iconographic model of Marlon Brando. Stanley is the quintessential representation of tough manliness, brutality, 
and violence as masculine nature. His machismo promptly falls and breaks into pieces when he both confronts Stella's challenges and the ridiculous tone of the play that does not allow him to perform a real version of the original play. Despite his strong sense of masculinity, when he becomes a customs agent to search through Blanche's personal stuff, he begins to wear Blanche's clothes just for the joy of it, resulting in an attempt to parody both sides of gender expression. Stanley represents the lesbian body and butch sexual desire, although-similarly to the original playhe has assumed a wrong sense of masculinity. This is evident from the way he talks to both his wife Stella and Blanche: "When are you hens gonna end that conversation?" (160). His imposed superiority is quickly disarmed by his illogical fear of darkness. This could be read as an emotional front built to avoid showing off his real identity that would make him come out of the closet. Instead, he challenges Mitch to wrestle and feels the need to uphold his identity-the same way macho men need to-as if masculinity were something that could be materialized. Of course, this fear of femininity arises from Stanley's subconscious which warns of the loss of his authoritative position and male privileges. It is not until later in Act Two when Stanley makes his first confession, exposing publicly his true nature:

I feel I'm never safe [...] I was born this way. I didn't learn it at theatre school. I was born butch. I'm so queer I don't even have to talk about it. [...] I'm just thousands of parts of other people all mashed into one body. I am not an original person. I take all these pieces, snatch them off the floor before they get swept under the bed, and I manufacture myself. When I'm saying I fall to pieces, I'm saying Marlon Brando was not there for me. (177)

This acknowledgment of his butch identity is proven here to be both performative and natural. Firstly, it is pure because gender roles are easily learned in the early years of life and they adjust pretty much to the personality of each person. However, they are also-as theorized by Butler-performative because they are learned, imitated, and reproduced to the maximum exponent in some cases. Movie star Marlon Brando would be an example of the degree that masculinity can be assumed and represented in a primitive way. In this case, Stanley rallies against the stereotype of masculinity created by the cinematographic industry since it does 
not suit lesbian identities and, what is worse, contributes to the exclusion of dissident masculinities and forces lesbians to acquire awry notions of expressing manhood. In addition, this masculinity by being expressed and performed onstage by a lesbian woman, confirms the instability of gender roles and their artificial nature as stereotypes created and portrayed by famous actors such as Marlon Brando. Then, if masculine behaviors can be perfectly imitated and reproduced by a lesbian, this fact probably suggests the ontological uncertainty of masculinity as a human social behavior. This way of reversing roles certainly suits camp purposes when being influenced by the gay sensibility.

The character of Mitch, who is described in the script as "a fairy disguised as a man" (150) and interpreted by Paul Shaw, one of the members of the troupe Bloolips, could be interpreted quite similarly. Mitch, as the antithesis of Stanley, portrays femininity from the stereotype of a gay man. Mitch represents the faggot, the fake male, the sissy boy, and the deconstruction of masculinity in general. Since the beginning of the play, he seems to show a lively interest in the rape scene played by Stanley on Blanche, which gives a clue of his possible sexual interest in Stanley. Again, the existent duality of sexual attractions between male/female and heterosexual/homosexual relations depending on how one reads the role of each character is given, a fact that reinforces the theoretical notions and the need to re-write subjecthood and to bring a multiplicity of characters to the stage, an action that would eventually lead to real inclusion. This way, the arms wrestling scene becomes a reflection on the weakness of gender roles as well as evincing the social construction of the biological idea and the roles associated to each sex/gender. Thus, in the socially-thought macho challenge, Mitch and Stanley become antonyms of the possible ways in which gender can be de-constructed and reconstructed but valid in any case. In this case, Mitch, who is trying to hide his queerness under his businessman's disguise, reveals his fascination for Stanley in a comic way:

STANLEY: (challenging him to arm wrestle) My big pioneer hands all over her rocky mountains.

MITCH: (taking the challenge) All over her livestock and vegetation. STANLEY: Her buffalos and prairies.

MITCH: Her thick forests and golden sunsets.

STANLEY: All over her stars! 
MITCH: She's in your hands!

STANLEY: She's in my hands and... yeeaaa... (he pins Mitch's arms down)

MITCH: That's right! Bite me! Bite me! Suck on me... oops.

STANLEY: (pulling away from Mitch) What are you talking about? MITCH: Mosquitoes! Biting me, biting me... (162-3)

The poetic language Mitch uses throughout the play recalls Allan Grey, Blanche's suicidal gay husband in Williams' play. Mitch then could be regarded as the personification of this character who died for revealing his true self. For this reason, Mitch does not seem to be as much interested in Blanche as he is in Stanley. As Solomon puts it: "Stanley and Mitch [are] parody paroxysms of male homosocial competition, each topping the other's declarations of blustery masculinity." (153-4). Mitch's heterosexual pretension is dismantled by himself in a monologue that explains his story about rejection. By being rejected he also restrains that queer part of his own nature which leads him to loneliness: "I think it all started to go wrong when I wasn't allowed to be a boy scout. [...] Then one day I fell in love with a beautiful young man. [...] Soon the boy left. [...] Then I was alone." (178).

Blanche is, along with Stanley, the other main character in Belle Reprieve, both because of her essential role in the narrative of the play and her gender deconstruction as a drag queen. According to the script, Blanche is described as "a man in a dress" (Split Britches 150), this is, the performer Bette Bourne, a famous British actor, drag queen, and activist gets cross-dressed on the stage to play the role of an eccentric woman. Thus, Blanche in this play can be read from multiple perspectives to which it should be added the role of Vivien Leigh who Blanche sometimes believes to embody. This iconic star is-the same way Marlon Brando influenced Stanley's behavior-the highest expression of femininity. Blanche as a drag queen is going to exaggerate in a comic way the attitudes assumed by the extremely stereotyped femininity Vivien Leigh portrays, making a campy version of the movie idol. In the very first intervention, Blanche declares her intentions by reconstructing the renowned phrase: "I've always depended on the strangeness of strangers." (151). For strangeness she means queerness, something that widens the possible perspectives from the beginning of the play, calling the audiences' attention by alluding to a famous statement that has been re- 
written. Throughout the play, the first barrier she encounters is when Stanley becomes a customs agent, her identity is requested, and her luggage is all muddled. Since her passport picture does not correspond to what Blanche has become, she answers: "The information in that document is a convention which allows me to pass in the world without let or hindrance." (153), and by convention she means all the possible stereotypes fixed within the binary gender system.

Blanche's prior subject has died, which has allowed room for her real identity. Yet, the Blanche written here is one who is clever, ironic, and powerful, and who does not tolerate intimidation or abuse, so she makes claims such as: "What right have you to interfere with nature?" (156), in response to Stanley's violent behavior towards the swans in the box. Her relationship with Mitch is-as shown by his little interest in her-comic, almost ridiculous and their only encounter is reduced to a scene where Mitch pulls out snot from Blanche's nose. The subtext of the finger sticking into her nose could be interpreted as a metaphorical sexual penetration between a gay man and a drag queen. This scene was obviously written with touches of what Charles Ludlam understood for Ridiculous Theater, one where the ridiculous parody leads to a more interesting political subtext. Furthermore, Blanche's famous rape scene gets subverted as she demands more realism for the play, yet her claim is both clear and funny: "I don't want to get raped and go crazy. I just wanted to wear a nice frock, and look at the shit they've given me!" (181). The very comic scene wrecks all those initial intentions of the original play and the dramatic tone is substituted by a ridiculous performance, mocking this way Williams' sense of reality that led him to represent a rape on the stage.

The beginning of the play is in every sense a political act like a 'coming out of the closet' as Mitch announces: "At four o'clock in the morning $[\ldots]$ the creatures that never see sunlight come out to make mincemeat" (150). Then Stella plays her part by introducing herself in the form of a metacommentary that makes the audience being aware of the explicit sensuality she represents: "Is there something you want? [...] You want my body. My soul, my food, my bed, my skin, my hands? You want to touch me, hold me, lick me, smell me, eat me, have me?" (150). With this eroticism in her words, Stella is claiming the passive and sexualized role she has in Williams' original play. On the other hand, Blanche makes 
a tremendous entrance by leaving the box (a symbol for the closet) where she was hidden and saying: "I've always depended on the strangeness of strangers." (151). With this sudden appearance and re-writing of Blanche's famous utterance and identity, it is being reaffirmed the necessity of exposing one's real nature and assume it most naturally. As well, there is a rapid change in the way the characters talk to each other, since they can easily jump from one narrative into another, resulting in the split of the narrative and the disassociation between the characters and the real performers. This way, they discuss early in the play the need to change the script as a means of deconstructing men's violence on women. Referring to the scene of the rape, they argue:

MITCH: Isn't there something you can do to stop it happening?

STELLA: Such as...

MITCH: Change the script!

STELLA: Change the script. Ha ha. You want me to do what in these shoes? The script is not the problem. I've changed the script.

MITCH: It's a start. (151)

The plot keeps the deconstruction through conversations that break up with the traditional narrative including split conversations, ridiculous scenes, jokes, and songs that have been slightly modified on purpose. For instance, while the naked light bulb symbolizes Blanche's fear for revealing her truths, in Belle Reprieve it applies to Stanley's fear for assuming his butch identity as he fears the darkness where he is hidden. As the play develops, when Blanche complains about the surrealistic tone of the play, Stella confirms: "realism works against us" (178), and thus, the separation between reality and fantasy becomes minimized. However, this assumption leads to the issue of the rape scene, which is deftly deconstructed by the troupe with a split conversation between Williams' play and Belle Reprieve as can be read in the following fragment:

BLANCHE: You wouldn't talk this way if you were a real man.

STANLEY: No, if I was a real man I'd say 'Come to think of it, you wouldn't be so bad to interfere with.

BLANCHE: And if I were really Blanche I'd say, 'Stay back... don't come near me another step... or I'll...

STANLEY: You'll what? 
BLANCHE: Something's gonna happen here. It will.

STANLEY: What are you trying to pull?

BLANCHE: (pulling off one of her stiletto-heeled shoes) I warn you... don't! (180).

The high-heel shoes substitute the glass bottle of the original play since they symbolize the quintessential representation of femininity. Yet this representation is reversed as one in which Blanche appears powerful and active, able to defend herself from Stanley, who tries to rape her. In this case, it is Stella who interrupts the scene: "Gimme that shoe!" (181) and they all start singing the "Pushover" song. Hence, the rape scene is deconstructed with a cross-dressing representation of Blanche that opposes Stanley's assumed realism that works against women's integrity as he says: "If you want to play a woman, the woman in this play gets raped and goes crazy in the end." (181). The drag representation brought by the character of Blanche is then essential to the purpose of deconstruction on both levels: characterization and plot development.

Belle Reprieve, in terms of re-writing, becomes the ultimate representation that deals with issues of gender and sexuality since it queers Williams' violent and heteropatriarchal perspective in Streetcar. Through the same weight of irony and jokes, it re-writes social relations, gender assumptions, and traditional perspectives of making theater. For this, the re-writing of the play, its symbols and songs that are popular in the mainstream culture becomes essential and they form part of the subverting strategies planned by Split Britches. Hence, the theater of the ridiculous and the comic and ironic language becomes the perfect scenario for reappropriating meanings and, with that, the destabilization of ontological unmoving categories of gender.

\section{CONCLUSION}

The work of Split Britches has become undoubtedly an inspiration for many contemporary artists who try to challenge standardized notions of making theater and normalized identities. Hence, questioning the origins of such assumptions that have been largely proved to be actual productions of both political discourses and practices is now crucial to dismantle heteropatriarchal structures. 
It is the main purpose of this paper to evince the worth of Split Britches' play Belle Reprieve, so as to reconsider the importance that off-Broadway non-mainstream plays have in the education of a society in order to transform it. Its value is mainly triggered by the inclusion of much complex theoretical thought that serves theater and the audience with the purpose of resistance and rebellion. This way, Belle Reprieve clearly reflects Lacan's theory of the Other from the perspective of Butler's critique. Refusing a pre-existing entity, the play shows how categorical assumptions are formed through language, discourses and practices and thus, they can be subverted in order to make society a more inclusive place. The play attempts to deconstruct unceasingly the political categories of the body in terms of biological sex, gender and sexual desire through crossdressing/drag devices along with a parody camp that emerges from the incongruity of any attempt to categorize. As well, Belle Reprieve fulfills to a large extent the purposes of political theater insofar as it adapts similar techniques such as sober settings and props, the destruction of the fourth wall or a direct communication between performer-audience. This allows critical thinking and a direct reference to the political meaning of everything that is constituted as personal. Hence, by demonstrating the objectification of women in William's play and dismantling the culturally constructed categories, the play reflects the possibility to revolt against the traditional model of subject construction provided by psychoanalysis. This way, desire, which was represented as exclusively male, changes the axis of its representation and in Belle Reprieve it is female desire which is proven to be more subversive.

In terms of subversion, Split Britches' play also depicts eloquently the weakness of male power through its obtuse employment of parody, ironic commentaries and sometimes ridiculous scenes that, by embracing failure and non-sense, expose the incongruence of the heteronormative articulations of gender and desire. It is only through an adequate use of comedy, irony and theatrical performance that the audience is able to understand the powerful subversive intention.

Although this play must be understood within its cultural and literary context of the nineties, a continuous review of it is still both plausible and necessary in order to extend its value and relate to it to recent gender theories. As well, it seems still needed 
in the present to emphasize the contributive worth that Split Britches offered to society from the literary field by approaching academic thought to mass audiences and introducing then, from the margins of the system, a more open alternative proposal of constructing the postmodern and poststructuralist subject.

\section{WORKS CITED}

AUSTIN, J. L. How To Do Things With Words. 1962. Harvard University Press, 1975.

BEAUVOIR, Simone de. Second Sex. Vintage Books, 1991.

BOTTOMS, Stephen J. Playing Underground: A Critical History of the 1960s Off-Off-Broadway Movement. The University of Michigan Press, 2009.

BUTLER, Judith. Bodies That Matter: On the Discursive Limits of "Sex". Routledge, 1993.

---. Excitable Speech. A Politics of the Performative. Routledge, 1997.

---. Gender Trouble. Feminism and the Subversion of Identity. Routledge, 1999.

---. Undoing Gender. Routledge, 2004.

CASE, Sue-Ellen. Feminist and Queer Performance: Critical Strategies. Palgrave Macmillan, 2009.

---. Split Britches: Lesbian Practice/Feminist Performance. Routledge, 1996.

ESTEBAN MUÑOZ, José. Disidentifications: queers of color and the performance of politics. University of Minnesota Press, 1999.

FORTE, Jeanie. "Women's Performance Art: Feminism and Postmodernism". Performing Feminisms: Feminist Critical Theory and Theatre, edited by Sue-Ellen Case. The Johns Hopkins University Press, 1990, pp. 251-269.

HALBERSTAM, Jack. Female Masculinity. Duke University Press, 2018.

HUTCHEON, Linda. A Theory of Parody. The Teachings of Twentieth-Century Art Forms. University of Illinois Press, 2000. 
JAMESON, Fredric. Postmodernism, or, The Cultural Logic of Late Capitalism. Duke University Press, 2012.

KUSHNER, Tony. "Notes about Political Theater." The Kenyion Review, vol. 19, no. 3/4 (Summer - Autumn), 1997, pp. 19-34.

LACAN, Jacques. Écrits. A selection. Routledge, 2001.

NEWTON, Esther. Mother Camp: Female Impersonators in America. University of Chicago Press, 1979.

SALIH, Sara. Judith Butler. Routledge, 2002.

SOLOMON, Alisa. Re-Dressing the Canon: Essays on Theater and Gender. 1998. Routledge, 2005.

WITTIG, Monique. The Straight Mind and Other Essays. Beacon Press, 2002. 